Sprawozdania / Reports

Krzysztof Grablewski

ORCID: 0000-0003-2703-8749

k.grablewski@pwsz.elblag.p1

Państwowa Wyższa Szkoła Zawodowa w Elblagu Instytutu Ekonomiczny

\title{
Ogólnopolska Konferencja Naukowa „Samorząd terytorialny w Polsce - stan obecny i perspektywy", Elbląg, 9 października 2020 r.
}

DOI: $10.34739 /$ doc.2021.18.24

Trzydzieści lat temu został rozpoczęty w Polsce proces odbudowy samorządu terytorialnego. Trzy dekady jego funkcjonowania pozwalaja na pogłębiona analizę problemów oraz na wyciagnięcie wniosków. Należy zastanowić się, jakie rozwiązania się sprawdzaja, jakie $z$ kolei trzeba poprawić, zmienić, uzupełnić. Rozwój samorza$\mathrm{du}$ terytorialnego w Polsce jest jednym $z$ najważniejszych fundamentów ustrojowych III Rzeczypospolitej. 8 marca 1990 r. została przyjęta ustawa, która zapoczątkowała proces budowy demokratycznego samorzadu. W dokumencie zapisano iż „mieszkańcy gminy tworza $z$ mocy prawa wspólnotę samorządowa”. Rozwój samorządu terytorialnego w Polsce miał wpływ na demokratyzację systemu politycznego. W następnych latach przeprowadzono kolejne reformy. Kluczowe okazały się zmiany z dnia 1 stycznia 1999 r., które wprowadzały samorząd powiatowy i wojewódzki. W artykule 15 Konstytucji RP z 1997 r. zapisano zasadę decentralizacji („Ustrój terytorialny Rzeczypospolitej Polskiej zapewnia decentralizację władzy publicznej"), która stanowi jedna z zasad ustrojowych Polski. W wyniku reformy wiele zadań państwa przeniesiono na szczebel samorządowy. Reformy wpłynęły także na rozwój partycypacji lokalnej. Budowano instytucje demokracji obywatelskiej, które miały z kolei wpływ na kształtowanie się społeczeństwa obywatelskiego. 
Organizatorem konferencji był Instytut Ekonomiczny Państwowej Wyższej Szkoły Zawodowej w Elblagu. Patronat honorowy objał dr Gustaw Marek Brzezin, marszałek województwa warmińsko-mazurskiego. Patronat medialny sprawowała: Elbląska Gazeta Internetowa portEl.pl; Truso.tv. Konferencja była przeprowadzona w trybie zdalnym. W skład Komitetu Programowego weszli: prof. dr hab. Marek Chmaj, kierownik Katedry Prawa Publicznego i Praw Człowieka, Wydział Prawa SWPS w Warszawie, prof. dr hab. Roman Kisiel, dziekan Wydziału Nauk Ekonomicznych Uniwersytetu Warmińsko-Mazurskiego w Olsztynie, prof. dr hab. Dariusz Szpoper, dyrektor Instytutu Prawa i Administracji w Akademii Pomorskiej w Słupsku, dr hab. Jerzy Przyborowski, prof. UWM, prorektor ds. kształcenia i studentów Uniwersytetu Warmińsko-Mazurskiego w Olsztynie, prof. dr hab. Nelly Daszkiewicz, Katedra Nauk Ekonomicznych Wydziału Zarządzania i Ekonomii Politechniki Gdańskiej, mł. insp. dr hab. Agata Tyburska, prorektor ds. Rozwoju Wyższej Szkoły Policji w Szczytnie, prof. dr hab. Tomasz Bakowski, kierownik Katedry Prawa Administracyjnego Wydziału Prawa i Administracji Uniwersytetu Gdańskiego, dr hab. Piotr Uziębło, prof. UG, prodziekan Wydziału Prawa i Administracji Uniwersytetu Gdańskiego. Natomiast w skład Komitetu Organizacyjnego weszli: mgr inż. Krzysztof Starańczak, dyrektor Instytutu Ekonomicznego PWSZ w Elblagu (przewodniczacy Komitetu Organizacyjnego) dr hab. Krzysztof Sidorkiewicz, prof. PWSZ, zastępca dyrektora Instytutu Ekonomicznego ds. naukowych i organizacyjnych PWSZ w Elblagu, mgr Katarzyna Olszewska, zastępca dyrektora Instytutu Ekonomicznego ds. kształcenia PWSZ w Elblagu, dr Olga Filaszkiewicz, Instytut Ekonomiczny PWSZ w Elblągu, dr inż. Tomasz Winnicki, Instytut Ekonomiczny PWSZ w Elblagu, dr Henryk Gawroński, Instytut Ekonomiczny PWSZ w Elblagu.

Organizatorzy zaproponowali uczestnikom konferencji następujace zagadnienia:

I. Organizacja i zadania samorządu terytorialnego: wójt (burmistrz, prezydent); rada/sejmik i ich funkcjonowanie; radny; wzajemne relacje organów samorządowych:

II. Wybory samorzadowe: system wyborczy; proces wyborczy; polityczne aspekty wyborów; 
III. Zmiany strukturalne: gmina - kwestie granic; scalanie gmin; powiat - łączenie; perspektywy; województwo - funkcjonowanie; przyszłość; metropolie;

IV. Partycypacja obywatelska: formy partycypacji obywatelskiej; referendum; budżet obywatelski; konsultacje społeczne; partnerstwa lokalne i lokalne grupy działania;

VI. Ochrona samodzielności samorzadu terytorialnego: niezależność samorządu terytorialnego, gwarancje samodzielności finansowej, środki pozwalające na weryfikację rozstrzygnięć nadzorczych;

V. Finanse samorzacdowe: polityka finansowa na szczeblu lokalnym; fundusze europejskie a samorzad lokalny;

VI. Zapewnienie dostępu do usług publicznych przez samorząd terytorialny: edukacja, pomoc społeczna i ochrona rodziny, sport i rekreacja, promocja zatrudnienia, wodociagi i kanalizacja, komunikacja miejska i inne;

VII. Gospodarka przestrzenna, rewitalizacja i ochrona środowiska: studium uwarunkowań i kierunków zagospodarowania przestrzennego, plany zagospodarowania, inwestycje celu publicznego, ocena oddziaływania na środowisko, lokalne plany rewitalizacji;

VIII. Instrumenty rozwoju terytorialnego i zarzadzania: zintegrowane inwestycje terytorialne, specjalne strefy ekonomiczne, parki technologiczne, centra usług wspólnych, rządowe programy wsparcia samorządów, itp.;

IX. Działania samorządu na rzecz bezpieczeństwa lokalnych społeczności: zarzadzanie kryzysowe w samorządzie; funkcjonowanie powiatowych komisji bezpieczeństwa i porządku.

Podczas konferencji zostały zaprezentowane referaty, opublikowane następnie w formie dwóch monografii naukowych: Ekonomiczne $i$ spoleczne aspekty rozwoju samorzadu terytorialnego $w$ Polsce pod redakcja Henryka Gawrońskiego, Katarzyny Olszewskiej, Krzysztofa Sidorkiewicza, Krzysztofa Starańczaka oraz Prawne uwarunkowania funkcjonowania samorzadu terytorialnego $w$ Polsce zredagowane przez ten sam zespół. Recenzentami publikacji byli: dr hab. Krzysztof Grzelec, prof. UG, dr hab. Krzysztof Krukowski, prof. UWM, prof. dr hab. Tomasz Bakowski oraz $\mathrm{dr}$ hab. Anna Rytel, prof. UG. 
Konferencja cieszyła się dużym zainteresowaniem pracowników naukowych, praktyków związanych $z$ samorządem terytorialnym oraz studentów. Podczas konferencji przedstawiono ekonomiczne i społeczne aspekty rozwoju samorzadu terytorialnego w Polsce. Prof. dr hab. Roman Kisiel, dr Magdalena Wojarska i mgr Emil Walendzik z Uniwersytetu Warmińsko-Mazurskiego w Olsztynie zaprezentowali temat: „Zintegrowane Inwestycje Terytorialne doświadczenia we wdrażaniu na przykładzie województwa warmińsko-mazurskiego". Zintegrowane inwestycje terytorialne (ZIT), zgodnie $z$ założeniami, sa instrumentem rozwoju terytorialnego szczególnie ważnym dla osiagania celów strategii Europa 2020. Również na poziomie regionalnym maja się przyczyniać do rozwoju głównych miast i pozytywnie wpłynąc na rozwój całych regionów. Autorzy podjęli próbę oceny na tle innych działań wdrażanych $\mathrm{w}$ regionalnych programach operacyjnych oraz w kontekście realizacji celów przyjętych dla ZIT.

Dr inż. Marcin Bukowski z Państwowej Wyższej Szkoły Zawodowej w Elblagu przedstawił temat: „Rola parków technologicznych w rozwoju regionów na przykładzie Elblasskiego Parku Technologicznego". Autor poddał ocenie efekty funkcjonowania polskich parków technologicznych. Przedstawiono znaczenie parków technologicznych i ich wpływ na rozwój gospodarczy regionu, w którym funkcjonuja. Opisano działalności parków technologicznych w Polsce. Szczegółowo scharakteryzowano funkcjonowanie Elbląskiego Parku Technologicznego oraz omówiono działania podejmowane przez park dla rozwoju przedsiębiorczości w mieście i regionie.

Dr Joanna Rosłon-Żmuda $z$ Uniwersytetu Gdańskiego zaprezentowała temat: „Działania samorządu województwa pomorskiego na rzecz zwiększenia atrakcyjności inwestycyjnej Pomorza”. Bardzo istotnym elementem gospodarki na każdym etapie jej rozwoju jest atrakcyjność inwestycyjna, która bezpośrednio przyczynia się do poprawy konkurencyjności i wzrostu aktywności gospodarczej wybranych obszarów. Autorka uznała, że nie bez znaczenia dla zwiększenia atrakcyjności inwestycyjnej sa działania władz regionalnych i lokalnych na rzecz tworzenia dogodnych warunków dla potencjalnych inwestorów czy rozwijania innowacyjnych działów gospodarki, co z kolei pozwala na poprawę pozycji konkurencyjnej regionów. 
Lic. Karol Szymon Orzeszak z Uniwersytetu Kazimierza Wielkiego w Bydgoszczy omówił temat: „Problematyka regionalnego zróżnicowania wynagrodzeń i aktywności inwestycyjnej przedsiębiorstw". Miasta i regiony o silnej marce odnotowują dodatnie saldo migracji, a także wzrost inwestycji, a w ślad za tym, jako następstwo obserwuje się tam wysokie wynagrodzenia. Autor stwierdza, że istotna rolę $\mathrm{w}$ kształtowaniu wizerunku miasta odgrywa obecność renomowanych uczelni, bowiem przedsiębiorcy prowadzacy prace badawczo-rozwojowe poszukuja dobrze wykształconych i kreatywnych pracowników.

Następnie Bartłomiej Wasiak z Państwowej Wyższej Szkoły Zawodowej w Elblagu podją temat: „Bariery warunkujące mobilność przestrzenna w ramach granic jednostek samorząów terytorialnych". Autor omówił czynniki, które warunkują mobilność przestrzenna $\mathrm{w}$ ramach granic jednostek samorząów terytorialnych w Polsce. Wskazano także na ekonomiczne czynniki mające istotny wpływ na napływ ludności na dany teren.

Dr Krzysztof Ćwieląg z Uniwersytetu Opolskiego zaproponował temat: „Wieloletnia prognoza finansowa jako instrument oddziaływania na poprawę samorządowej gospodarki finansowej”. To instrument, który ma wspomagać samorządową gospodarkę finansową i przyczyniać się do jej usprawnienia. Autor podejmuje próbę odpowiedzi na pytanie, czy w obecnym kształcie można uznać ją za instrument zarzadzania finansami i jakie warunki powinna spełniać, aby mogła oddziaływać na poprawę samorządowej gospodarki finansowej.

Dr Hanna Kruk z Parku Krajobrazowego Wysoczyzny Elblaskiej omówiła temat: „Funkcjonowanie parków krajobrazowych jako jednostek organizacyjnych samorządu województwa na przykładzie Parku Krajobrazowego Wysoczyzny Elbląskiej”. Od 2009 r. PK stały się jednostkami organizacyjnymi samorządu województwa. Autorka dokonuje analizy zmian prawnych wpływajacych na funkcjonowanie PK w kolejnych latach, a na przykładzie Parku Krajobrazowego Wysoczyzny Elbląskiej przedstawia realizowane zadania i źródła finansowania działalności parku w latach 2009-2019.

Mgr Piotr Pieńkosz z Uniwersytetu Kardynała Stefana Wyszyńskiego w Warszawie przedstawił temat: „Samorzad terytorialny jako kreator innowacyjnych rozwiązań na przykładzie systemu 
e-kontrole wdrożonego w strefie płatnego parkowania w Warszawie". Autor postawił sobie za cel uzyskanie odpowiedzi na pytanie, w jaki sposób jednostka samorządu terytorialnego może stać się kreatorem innowacyjnego rozwiązania. Projektowanie, również $z$ udziałem sektora prywatnego, a następnie wdrażanie innowacji może być motywowane chęcią bardziej efektywnej realizacji zadań publicznych. Przedmiotem opracowania jest również weryfikacja warunków, jakie muszą zaistnieć, aby wdrożenie innowacji w samorządzie terytorialnym przyniosło oczekiwane pozytywne efekty.

Lic. Oskar Sęk z Państwowej Wyższej Szkoły Zawodowej w Elblagu omówił temat: „Postawy Polaków wobec pomocy społecznej w systemie samorządu terytorialnego". Autor w części teoretycznej opisał historię pomocy społecznej z podziałem na trzy okresy - pierwszy od 1918 r. do 1939 r., drugi od 1945 r. do 1989 r. oraz trzeci od 1989 r. do 2018 r. W części praktycznej zaprezentowano wyniki badań ankietowych, zrealizowanych w sierpniu 2019 r. na 731 respondentach oraz na przełomie lutego i marca 2020 r. na 1612 ankietowanych. Pomoc społeczna jest postrzegana negatywnie, zarówno w ujęciu systemowym i lokalnym, a także od strony interesariuszy i społeczeństwa. Zmiana tego stanu rzeczy wymaga opracowania przemyślanych reform i zmian, które będa rozwiązywać dotychczasowe problemy.

Następnie dr inż. Anetta Waśniewska z Uniwersytetu Morskiego w Gdyni podjęła temat: „Determinanty funkcjonowania organizacji pozarządowych w województwach (wybrane czynniki)". Działalność organizacji pozarządowych nie jest nastawiona na maksymalizację zysku, ale przede wszystkim na poprawę sytuacji społeczności zamieszkującej obszar jej działalności. Najczęściej podejmowane przez organizacje działania dotycza pomocy osobom znajdującym się w tzw. grupach defaworyzowanych. Autorka określa czynniki wpływające na funkcjonowanie organizacji pozarząowych.

Dr Emilia Kalitta $z$ Sopockiej Szkoły Wyższej wybrała temat: „Budżet obywatelski jako forma obywatelskiego zaangażowania w sprawy lokalne". Autorka porusza tematykę budżetu obywatelskiego jako szczególnej formy konsultacji społecznych, która zarówno umożliwia mieszkańcom współdecydowanie o budżecie sa- 
morządowym, ale jednocześnie nakłada na nich odpowiedzialność za realizację tego budżetu.

Natomiast mgr Joanna Radzioch z Uniwersytetu im. Adama Mickiewicza w Poznaniu zaprezentowała temat: „Funkcjonowanie budżetu partycypacyjnego we Wrocławiu w latach 2013-2019”. Budżet partycypacyjny jest istotnym narzędziem służącym rozwojowi udziału społeczeństwa we współdecydowaniu o otoczeniu. Implikacja tego rozwiązania stała się popularnym zjawiskiem. Autorka przedstawia ocenę funkcjonowania budżetu partycypacyjnego we Wrocławiu w latach 2013-2019 oraz zaprezentowała zmiany w organizacji budżetu partycypacyjnego we Wrocławiu, a także odniosła się do danych zawartych $w$ raportach $z$ jego funkcjonowania.

Dr Jacek Pieczonka $z$ Uniwersytetu Opolskiego przedstawił temat: „Program odnowy wsi oraz fundusz sołecki jako instrumenty poprawiajace jakość kapitału społecznego obszarów wiejskich”. Autor prezentuje realizację działań finansowanych w ramach Programu Odnowy Wsi oraz Funduszu Sołeckiego (na przykładzie gminy Dąbrowa) jako elementu pobudzającego społeczności lokalne, wzmacniającego kapitał społeczny.

Następnie dr Maja Krasucka z Uniwersytetu Opolskiego zaprezentowała temat: „Potencjał finansowy sportowych organizacji pożytku publicznego". Autorka w swoich badaniach zidentyfikowała struktury przychodów niekomercyjnych organizacji realizujacych zadania sportowe oraz rozpoznanie zróżnicowania cech ich potencjału finansowego wynikającego $z$ udziału środków publicznych w przychodach ogółem. Badanie przeprowadzono w odniesieniu do OPP, realizujacych zadania w zakresie wspierania i upowszechniania kultury fizycznej na terenie województwa opolskiego w latach 2013-2017.

Mgr Sebastian Chrzanowski z Urzędu Miejskiego w Łomży zaprezentował temat: „Miasta partnerskie jako jedna $z$ form współpracy świadczaca o międzynarodowej aktywności polskich jednostek samorządu terytorialnego". Autor przybliżył początki samorządowej aktywności na arenie międzynarodowej, jej podstawy prawne, a także ideę funkcjonowania miast partnerskich oraz przykład Gminy Kobylnica.

Kolejnym istotnym aspektem były prawne uwarunkowania funkcjonowania samorządu terytorialnego w Polsce, które zostały 
przestawione podczas konferencji i w monografii pokonferencyjnej. Dr Katarzyna Jurewicz-Bakun z Państwowej Wyższej Szkoły Informatyki i Przedsiębiorczości w Łomży omówiła temat: „Samodzielność samorządu terytorialnego jako konstytucyjna gwarancja niezależności”. Autorka podkreśla, że samorządowi terytorialnemu w wykonywaniu zadań publicznych przysługuje atrybut samodzielności. Samodzielność samorządu nie ma jednak charakteru absolutnego. Konstytucja Rzeczypospolitej Polskiej oraz ustawy samorządowe przyjmuja, że samorząd terytorialny wykonuje w imieniu własnym i na własna odpowiedzialność przysługująca mu część zadań publicznych, a samodzielność samorządu podlega ochronie sąowej.

Dr Beata Słobodzian z Uniwersytetu Gdańskiego przestawiła temat: „Wybory samorzadowe 2018 roku a zmiany w organizacji wyborów". Od wielu lat można obserwować malejące zainteresowanie obywateli uczestnictwem w demokracji przedstawicielskiej. Jednym ze sposobów przeciwdziałania temu zjawisku sa zmiany zasad wyborczych, które przyczyniłyby się do wzrostu uczestnictwa w wyborach. Autorka stwierdza, że zmiany te (nowelizacja aktów prawnych) powinny być odpowiednio przygotowane, przemyślane i wprowadzane we właściwym czasie.

Dr hab. Piotr Uziębło, prof. uczelni z Państwowej Wyższej Szkoły Zawodowej w Elblagu przedstawił temat: „Kształt systemu wyborczego do rady miasta na prawach powiatu na przykładzie wyborów do Rady Miejskiej w Elblagu". Autor koncentruje się na analizie zasad funkcjonowania systemu wyborczego do rady miasta na prawach powiatu na przykładzie wyborów do Rady Miejskiej w Elblagu, które odbyły się od 2002 roku. W tym celu, po dokonanej analizie normatywnej, autor dokonał symulacji różnych, możliwych wariantów ukształtowania systemu wyborczego w celu oceny ich wpływu na ostateczny wynik wyborów.

Dr hab. Krzysztof Sidorkiewicz, prof. uczelni z Państwowej Wyższej Szkoły Zawodowej w Elblagu omówił temat: „Zmiany prawa wyborczego w wyborach samorządowych w latach 1990-2010 i ich skutki”. Autor charakteryzuje najważniejsze zmiany w ordynacji samorządowej, które nastapiły w latach 1990-2010. Poczatkowa cezura zwiazana jest $z$ odrodzeniem się samorzadu terytorialnego 
w Polsce. Autor analizował skutki wprowadzonych zmian, głównie w oparciu o frekwencję wyborczą.

Michał Kołbuc $z$ Uniwersytetu Mikołaja Kopernika w Toruniu zaprezentował temat: „Protest wyborczy jako sposób weryfikacji ważności wyborów samorządowych". Protest wyborczy jest przewidzianym przez prawo środkiem, który służy zakwestionowaniu i skontrolowaniu ważności wyborów. Autor przedstawił wyniki przeprowadzonej analizy przepisów obowiązującego prawa, doniesień prasowych, a także danych dotyczących postępowań w sprawach protestów wyborczych.

Patrycja Prasak z Uniwersytetu Mikołaja Kopernika w Toruniu omówiła temat: „Organ wykonawczy gminy w przeszłości i teraźniejszości. Wybrane aspekty”. Na przestrzeni lat dokonywano zmian w zakresie wyboru, odwołania, zadań oraz kadencyjności organu wykonawczego gminy. W założeniu kolejne ustawy nowelizujące miały prowadzić do wzmocnienia pozycji egzekutywy względem rady gminy. Autorka poddała analizie aspekty funkcjonowania organu wykonawczego gminy $z$ perspektywy uplywu trzydziestu lat od restytucji samorzadu terytorialnego, aby dostrzec rozwiązania zasługujące na aprobatę lub krytykę.

Natomiast dr hab. Zbigniew Kudrzycki, wójt gminy Rozogi przedstawił temat: „Partycypacja obywatelska w świetle ustawy o samorzadzie gminnym 1990-2018". Autor postawił pytanie, czy ustawa o samorządzie gminnym przed 2018 rokiem umożliwiała realny udział mieszkańców w sprawowaniu władzy i czy ostatnie zmiany legislacyjne moga spowodować wzrost partycypacji obywatelskiej w samorządzie gminnym.

Dr Karina Górska-Rożej z Akademii Sztuki Wojennej w Warszawie zreferowała temat: „Partycypacja społeczna, a budowanie odporności na zagrożenia w społecznościach lokalnych na przykładzie gminy". Partycypacja społeczna winna opierać się na trzech filarach: informowaniu, konsultowaniu oraz współdecydowaniu. Autorka stara się udzielić odpowiedzi na pytanie: jakie znaczenie odgrywa partycypacja społeczna w budowaniu odporności na zagrożenia w społecznościach lokalnych?

Jakub Skibiński z Uniwersytetu Marii Curie-Skłodowskiej w Lublinie przedstawił temat: „Uwarunkowania kształtowania polityki przestrzennej i kierunki rozwoju gminy uzdrowiskowej Hory- 
niec-Zdrój”. Znajdujące się w Horyńcu złoża leczniczej borowiny i wód mineralnych sa podstawa prowadzenia lecznictwa uzdrowiskowego i wpływaja na turystyczna popularność tego miejsca w kraju. Autor stwierdza, że występujące w gminie walory lecznicze, przyrodnicze i kulturowe, jak również bezpośrednie sąsiedztwo granicy kraju, w bardzo mocny sposób determinuja politykę przestrzenną.

Mgr inż. Karolina Trykacz z Uniwersytet Marii Curie-Skłodowskiej w Lublinie poruszyła temat: „Miejsce obszarów funkcjonalnych w polskim systemie planowania przestrzennego". Obszary funkcjonalne sa coraz częstszym przedmiotem dyskusji naukowych. Autorka proponuje rozwiązania, które pozwoliłoby na bardziej efektywne kształtowanie przestrzeni obszarów funkcjonalnych.

Kolejna prelegentka, mgr Magdalena Taraszkiewicz z Państwowej Wyższej Szkoły Informatyki i Przedsiębiorczości w Łomży przedstawiła temat: „Granice ingerencji gminy w prawo własności w planowaniu i zagospodarowaniu przestrzennym”. Prawo własności jest jednym $z$ podstawowych praw człowieka podlegajacym ochronie konstytucyjnej. Zasadniczym prawem właściciela nieruchomości jest możliwość korzystania $z$ niej $z$ wyłączeniem innych osób zgodnie ze społeczno-gospodarczym przeznaczeniem swojego prawa. W przypadku wykonywania przez gminę zadań zwiazanych z planowaniem i zagospodarowaniem przestrzennym prawo własności ulega ograniczeniom. Dochodzi więc do konfrontacji dwóch wartości konstytucyjnych: prawa własności oraz samodzielności gminy.

Dr Cezary Brzeziński z Państwowej Uczelni im. Stefana Batorego w Skierniewicach zaprezentował temat: „Reżim prawny planowania przestrzennego $\mathrm{w}$ Polsce i jego konsekwencje finansowoprzestrzenne. Wybrane problemy". Autor przedstawia finansowe i przestrzenne skutki planowania przestrzennego w Polsce wynikajacych $z$ ustanowionego prawa i jego interpretacji przez sady administracyjne. Zestawiono obowiąujące przepisy oraz dane statystyczne obrazujące dochody i wydatki zwiąane $z$ uchwaleniem i realizacja miejscowych planów zagospodarowania przestrzennego. Wskazano na konsekwencje przestrzenne obowiąującego prawa.

Dr Grażyna Cern z Państwowej Wyższej Szkoły Zawodowej w Elblagu poruszyła temat: „Zarobkowa działalność samorządu 
terytorialnego". Wzrastające znaczenie samorządności terytorialnej we współczesnym państwie połączone jest $z$ rozwijającymi się różnymi formami aktywności w zakresie prowadzenia działalności gospodarczej przez jednostki samorzadu terytorialnego. Autorka podejmuje próbę odpowiedzi na pytanie: czy jednostki samorządu terytorialnego moga bądź powinny taką działalność prowadzić?

Lic. Monika Hasić z Państwowej Wyższej Szkoły Zawodowej w Elblagu omówiła temat: „Społeczny odbiór straży gminnych”. Zebrany materiał empiryczny pozwolił wskazać autorce, które czynniki maja wpływ na pozytywny, a które na negatywny społeczny odbiór straży gminnych/miejskich oraz jakie zadania ta formacja powinna realizować, aby jej społeczny odbiór był pozytywny.

Następnie dr Dariusz P. Kała z Akademii EkonomicznoHumanistycznej w Warszawie poruszył temat: „Udoskonalanie zarządzania kryzysowego oraz bezpieczeństwa w gminie poprzez scalanie Ochotniczy Straży Pożarnych”. Autor skoncentrował się na omówieniu nieprawidłowości w praktyce funkcjonowania $\mathrm{i}$ finansowania ochotniczych straży pożarnych, które zostały dostrzeżone podczas kontroli dokonywanej przez Najwyższa Izbę Kontroli w 2019 r. Autor omówił wpływ tych zagadnień na funkcjonowanie systemu bezpieczeństwa i zarządzania kryzysowego w gminach oraz na efektywność wydatkowania środków publicznych. Zwieńczeniem było wskazanie rozwiązań, które mogłyby zapobiec omawianym problemom.

Mgr Violetta Radecka-Sinicka z Wojewódzkiego Sąu Administracyjnego w Opolu zaprezentowała temat: „Skarga na rozstrzygnięcia nadzorcze wojewody $w$ świetle orzecznictwa sąowoadministracyjnego". Autorka wskazała, że skarga do sądu administracyjnego, wnoszona przez gminy na rozstrzygnięcia nadzorcze wojewody, jest jedna $z$ podstawowych form ochrony samodzielności tych jednostek. Przedmiotem rozważań jest analiza orzecznictwa sadowo-administracyjnego $\mathrm{w}$ zakresie zagadnień dopuszczalności skargi jako bariery w skutecznym dochodzeniu przez gminy do obrony swoich interesów.

Dr Ewa Kosior z Państwowej Wyższej Szkoły Informatyki i Przedsiębiorczości w Łomży omówiła temat: „Odpowiedzialność gminy za jakość powietrza. Prawo do życia w niezanieczyszczonym środowisku jako prawo osobiste”. Władza publiczna ponosi odpo- 
wiedzialność odszkodowawcza, gdy zadania publiczne państwa nie sa realizowane lub sa wykonywane nieprawidłowo. Autorka wskazała, że zaniechanie lub nieprawidłowości w realizacji tych zadań moga skutkować odpowiedzialnością gminy także w oparciu o przepisy o ochronie dóbr osobistych i prowadzić do zasądzenia zadośćuczynienia (art. 24 k.c. w zw. z art. 448 k.c. i 417 k.c.). Za dobro osobiste może zostać uznane (nieskażone) środowisko.

Przedstawione podczas konferencji zagadnienia omawiały wybrane problemy ekonomiczne i społeczne, a także prawne $z$ zakresu zadań samorządu terytorialnego. Ogólnopolska Konferencja naukowa „Samorząd terytorialny w Polsce - stan obecny i perspektywy" doskonale wpisała się w upamiętnienie trzydziestolecia polskiego samorząu terytorialnego. Tego typu wydarzenia naukowe sa dobra okazją do spotkania badaczy i praktyków, co służy wymianie doświadczeń oraz wypracowaniu nowych rozwiązań. 